\title{
SOME BIOLOGICAL HEALTH HAZARDS AMONG SEWAGE WORKERS
}

\author{
By \\ Helal S.F. ${ }^{1}$, Rashed L.A. ${ }^{2}$, \\ From \\ 1] Department of Occupational Medicine \& Industrial Diseases. \\ 2] Department of Biochemistry. \\ Faculty Of Medicine . Cairo University.
}

\begin{abstract}
:
Objectives: The current work aimed at assessment of biological hazards among workers of sewer networks.

Subjects: The work was conducted on 34 male workers involved in the maintenance of the sewerage system network and a matched unexposed control group $(n=35)$.

Methods: (A) All workers were interviewed using a special questionnaire including occupational history ; and full clinical examination was performed. (B) Detection of HAV and HBV (C) Detection of leptospira spirochete antibodies in serum sample using monoclonal antibody technique. (D) Detection of leptospira spirochete in stool by polymerase chain reaction (PCR). (E) Detection of Helicobacter Pylori in blood sample by Ig G.

Results: We found that there were statistically significant differences between the exposed and the control groups as regards the presence of chronic infection with HAV and Helicobacter and of leptospira spirochete and the presence of abdominal pain and body aches. There was no statistically significant difference between sewage workers $\leq$ 20 years duration of exposure and those $>20$ years as regards HAV, HBV, Helicobacter and a statistically significant difference between both groups as regards leptospira spirochete infection.
\end{abstract}

Conclusion: There were statistically significant differences between the exposed and the control groups as regards the presence of chronic infection with HAV and Helicobacter and of leptospira spirochete and the presence of abdominal pain and body aches.

Recommendation: Biological hazards could be prevented through engineering, medical and legislative measures. The medical measures will help in early detection of the effects of these exposures. This can be partly achieved by developing an effective occupational health service for the workers. Regular awareness programs should be 
conducted to impart knowledge regarding safer work procedures, the use of personal protective devices and to avoid direct contact with raw sewage. For pipeline or other inspections, remote-controlled robotic cameras can minimize human exposure.

Key words: HAV, HBV, Helicobacter Pylori, Leptospirosis, Biological hazards.

\section{Introduction}

The sewerage system is a vast network of underground canals which duplicates nearly perfectly the street network. It drains the waste water towards the treatment plants. This system consists of three typical environments: small (primary) lines connect buildings to the sewerage system. When these lines need to be maintained, the sewer workers intervene directly with handheld tools. Secondary and main collectors (canals) group the output of the primary lines. These collectors are larger and small sidewalks allow the workers to walk along these canals. The clearing of these canals is done using wagons or boats allowing the regulation of the flow of the wastewater. More or less large sedimentation basins slow down the wastewater flow in order to get rid of the sediments (Walid et al ., 2006). Raw sewage and wastewater contain bacteria, fungi, parasites, worms, protozoa and viruses that can cause intestinal, lung, and other infections. If equipment, work practices, and personal protective equipment (PPE) don't protect the worker from getting in contact with these agents, the worker can get sick. The composition of the sewage can vary greatly based on geographical location (ACGIH) (2004). Leptospirosis is an important occupational disease affecting people coming in contact with animals such as rats, skunks, opossums, raccoons, foxes, and other vermin or their discharges. It is transmitted though contact with infected soil or water via broken skin and mucous membrane (eyes, nose, sinuses, mouth), or through ingestion of contaminated food or water (Ambekar et al., 2004) . Recent research has shown that workers with routine sewage exposures exhibit respiratory dysfunction, fatigue and headache, infection as viral A hepatitis and increased incidence of cancers . Thus, the need arises for adequate training, immunization, and the use of personal protective equipment that provides dermal, mucus membrane, and respiratory protection (Friis et al., 1996). Helicobacter pylori (H. pylori) is a bacterium that causes chronic inflammation of the inner lining of the stomach (gastritis) in humans. Helicobacter pylori causes chronic gastritis worldwide and it is the most important single factor in peptic ulcer disease (Rautelin and Kosunen 2004). During the last decade the bacterium Helicobacter pylori has emerged as one important risk factor for gastric cancer and 
is now considered a class I carcinogen by the International Agency for Research on Cancer. The route of transmission for this bacterium remains unclear, but fecal-oral transmission has been proposed (Friis et al., 1996).

\section{Aim of the work:}

The aim of the present study was to investigate some of the biological health hazards among sewage workers with special emphasis on the most common infections in sewage workers .

\section{Subjects and methods:}

This study was carried out on 34 littered male workers involved in maintenance of the sewerage system network of the regions El Manial, Misr el Kadema, and Kasr El- Eini hospital. The workers were responsible for inspection of lines in order to detect any perturbation of the waste water flow and possible defaults (for example, cracks, leaks) of the duct, the maintenance of the waste water lines and extraction of the sediments. Their frequency of exposure was about 3-4 times/week, each time of about 12 hours. Their ages varied between $31-54$ years $(43.73 \pm 5.40)$. None of the workers used any protective equipment during working hours. A referent group of 35 males matched for age [ that ranged from 30-48 yrs., (40.62 \pm 3.88$)$ ], sex, socio-eco- nomic status and smoking habits, selected from relatives of the Kasr El Eini hospital patients, were also enrolled in our study. The selection was on the basis of simple random sample from Thursdays out patient clinics. The following investigations were performed after taking individual consent:

(A) All workers were interviewed using a special questionnaire including occupational history ; and full clinical examination was performed. (B) Serum was examined for antibodies against HAV and HBV : Antibodies against $\mathrm{HAV}$ and $\mathrm{HBV}$ as $\mathrm{HBsAg}$ were determined by quantitative sandwich enzyme linked Immuno sorbent assay (ELI$\mathrm{SA})$. for detection of $\mathrm{IgG}$ in the sera of all cases, according to manufacturers recommendation. The kits were supplied by Ray Biotch, Inc.(Germany). (C) Examination of serum of leptospira spirochete using monoclonal antibody technique. (D) Analysis of stool by polymerase chain reaction (PCR): leptospira spirochete in stool by PCR according to the following steps:

\section{DNA extraction:}

Total DNA was extracted from samples using the SV total DNA isolation system kit (Promega, Madison, USA) according to the manufacturer's recommendations, extracted DNA were quantitated at $260 \mathrm{~nm}$ using spectrophotometer. 


\section{PCR:}

PCR reaction was performed by adding the PCR mix which contained $10 \mathrm{mmol}$ /L tris HCL PH 8.3, 2.3 unit of Taq polymerase, $100 \mathrm{mmol}$ dNTPS and $100 \mathrm{mmol}$ of each specific primer with the following sequence, forward : CAGCCTCTTGAGTAGCTGG-Reverse: TCAGGAGTTCGAGACCAGC. Then the reaction mixture was subjected to 40 cycles of $95^{\circ} \mathrm{C}$ for $1 \mathrm{~min}, 55^{\circ} \mathrm{C}$ for $1 \mathrm{~min}$ and $72^{\circ} \mathrm{C}$ for $2 \mathrm{~min}$. after the last cycle a final extension at $72^{\circ} \mathrm{C}$ for $10 \mathrm{~min}$ was done.

\section{Agarose gel electrophoresis:}

All PCR products were electrophoresed on $2 \%$ agarose stained with ethidium bromide and visualized by UV transilluminator. Fragment sizes were $113 \mathrm{pb}$.

\section{(E) Blood was examined for Helicobacter Pylori by Ig G.}

Blood tests check blood to see if the sample has antibodies which stick to $\mathrm{H}$. pylori. If antibodies were present, it means that either the individual has a current infection of $\mathrm{H}$. pylori or he has had an infection of H.pylori in the recent past (i.e. the past 3 years usually). However if the blood test is negative the individual can be reassured that he never had and he does not have an H.pylori infection. An enzyme-linked immunosorbent assay (ELISA) was used to investigate the prevalence of $\mathrm{H}$. pylori.

\section{Statistical analysis:}

Results were evaluated for each group. Data were compared using Student t test. Results of prevalence of some biological infections and trail making and alternating sequence tests were expressed as frequency distribution using chi ${ }^{2}$ test. Pearson correlation test was used to correlate between different variables among the exposed groups. The statistical significance was defined as $\mathrm{P}$-value $<0.05$. Computer based Statistical Package for Social Sciences (SPSS) for windows 9.1 program was used.

\section{Results:}

Table (1) shows statistically significant differences between the exposed and the control groups as regards the presence of chronic infection with HAV and Helicobacter and of Leptospira spirochete.

Table (2) shows statistically significant differences between the exposed and the control groups as regards the presence of abdominal pain and body ache.

Table (3) shows a statistically non significant difference between the sewage workers $\leq 40$ year and those $>40$ years as regards $\mathrm{HAV}, \mathrm{HBV}$ and Helicobacter infections and shows a statistically significant difference between both groups as regards the Leptospira spirochete. 
Table (4) shows a statistically significant difference between the sewage workers $\leq 40$ year and those $>40$ years as regards abdominal pain and body ache and statistically non significant difference as regards history of jaundice
Table (5) shows no statistically significant difference between sewage workers $\leq$ 20 years duration of exposure and those $>$ 20 years as regards HAV, HBV, Helicobacter and shows a statistically significant difference between both groups as regards leptospirosis infection.

Table (1) The incidence of some biological markers of infection among the examined groups:

\begin{tabular}{|l|c|c|c|c|c|c|}
\hline \multirow{2}{*}{} & \multicolumn{2}{|c|}{$\begin{array}{c}\text { Exposed group } \\
\text { N:34 }\end{array}$} & \multicolumn{2}{c|}{ Control group } & \multirow{2}{*}{ N:35 } & \multirow{2}{*}{$\begin{array}{c}\text { P } \\
\text { value }\end{array}$} \\
\cline { 2 - 6 } & $\mathrm{N}$ & $\%$ & $\mathrm{~N}$ & $\%$ & & \\
\hline HAV antibodies & 20 & 58.82 & 7 & 20 & 10.91 & $<0.05$ \\
\hline HBsAg & 13 & 38.23 & 6 & 17.14 & 3.84 & $>0.05$ \\
\hline $\begin{array}{l}\text { Helicobacter antibodies } \\
\text { IgG }\end{array}$ & 16 & 47.05 & 8 & 22.85 & 4.45 & $<0.05$ \\
\hline $\begin{array}{l}\text { Serum Leptospira } \\
\text { spirochete antibodies }\end{array}$ & 10 & 29.41 & 1 & 2.85 & 9.07 & $<0.05$ \\
\hline $\begin{array}{l}\text { Stool PCR for Leptospira } \\
\text { spirochete }\end{array}$ & 16 & 47.05 & 4 & 11.42 & 10.63 & $<0.05$ \\
\hline
\end{tabular}


Helal S.F. et al.,

Table (2) Symptoms related to infections among the examined groups:

\begin{tabular}{|c|c|c|c|c|c|c|}
\hline & \multicolumn{2}{|c|}{$\begin{array}{c}\text { Exposed group } \\
\qquad \mathrm{N}: 34\end{array}$} & \multicolumn{2}{|c|}{$\begin{array}{c}\text { Control group } \\
\qquad \mathrm{N}: 35\end{array}$} & \multirow[t]{2}{*}{$\mathbf{X}^{2}$} & \multirow[t]{2}{*}{$P$ value } \\
\hline & $\mathbf{N}$ & $\%$ & $\mathbf{N}$ & $\%$ & & \\
\hline Abdominal pain & 16 & 47.05 & 7 & 20 & 5.68 & $<0.05$ \\
\hline History of jaundice & 7 & 20.58 & 3 & 8.57 & 2.02 & $>0.05$ \\
\hline Body ache & 10 & 29.41 & 1 & 2.85 & 9.07 & $<0.05$ \\
\hline
\end{tabular}

Table (3) The relation between the incidence of some infections and the age of the sewage workers:

\begin{tabular}{|c|c|c|c|c|c|c|}
\hline & \multicolumn{2}{|c|}{$\begin{array}{c}\text { Age } \leq 40 \text { years } \\
\text { N: } 10\end{array}$} & \multicolumn{2}{|c|}{$\begin{array}{c}\text { Age }>40 \text { years } \\
\text { N: } 24\end{array}$} & \multirow[t]{2}{*}{$\mathbf{X}^{2}$} & \multirow[t]{2}{*}{ P value } \\
\hline & $\mathbf{N}$ & $\%$ & $\mathbf{N}$ & $\%$ & & \\
\hline HAV antibodies & 6 & 60.00 & 14 & 58.33 & 0.008 & $>0.05$ \\
\hline HBsAg & 4 & 40.00 & 9 & 37.50 & 0.01 & $>0.05$ \\
\hline $\begin{array}{l}\text { Helicobacter antibodies } \\
\text { IgG }\end{array}$ & 4 & 40.00 & 12 & 50.00 & 0.28 & $>0.05$ \\
\hline $\begin{array}{l}\text { Serum Leptospira } \\
\text { spirochete antibodies }\end{array}$ & 0 & 0.00 & 10 & 41.66 & $\begin{array}{l}5.90 \\
\text { FisherX } X^{2}\end{array}$ & $<0.05$ \\
\hline $\begin{array}{l}\text { Stool PCR for } \\
\text { Leptospira spirochete }\end{array}$ & 1 & 10.00 & 15 & 62.50 & 7.80 & $<0.05$ \\
\hline
\end{tabular}


Table (4) Relation between the age of the exposed workers and some symptoms:

\begin{tabular}{|c|c|c|c|c|c|c|}
\hline & \multicolumn{2}{|c|}{$\begin{array}{c}\text { Age } \leq 40 \text { years } \\
\text { N:10 }\end{array}$} & \multicolumn{2}{|c|}{$\begin{array}{c}\text { Age }>40 \text { years } \\
\text { N:24 }\end{array}$} & \multirow[t]{2}{*}{$\mathbf{X}^{2}$} & \multirow[t]{2}{*}{ P value } \\
\hline & $\mathbf{N}$ & $\%$ & $\mathbf{N}$ & $\%$ & & \\
\hline Abdominal pain & 2 & 20.00 & 14 & 58.33 & 4.16 & $<0.05$ \\
\hline History of jaundice & 3 & 30.00 & 4 & 16.66 & 3.51 & $>0.05$ \\
\hline Body ache & 0 & 0.00 & 10 & 41.66 & $\begin{array}{l}5.90 \\
\text { Fisher } X^{2}\end{array}$ & $<0.05$ \\
\hline
\end{tabular}

Table (5) The relation between duration of exposure of sewage workers and the results of different investigations:

\begin{tabular}{|c|c|c|c|c|c|c|}
\hline & \multicolumn{2}{|c|}{$\begin{array}{c}\begin{array}{c}\text { Duration } \leq 20 \\
\text { years }\end{array} \\
\mathrm{N}: 22\end{array}$} & \multicolumn{2}{|c|}{$\begin{array}{c}\text { Duration }>20 \\
\text { years } \\
\text { N:12 }\end{array}$} & \multirow[t]{2}{*}{$\mathbf{X}^{2}$} & \multirow[t]{2}{*}{ P value } \\
\hline & $\mathbf{N}$ & $\%$ & $\mathbf{N}$ & $\%$ & & \\
\hline HAV antibodies & 12 & 54.54 & 8 & 66.66 & 0.47 & $>0.05$ \\
\hline HBsAg & 8 & 36.36 & 5 & 41.66 & 0.09 & $>0.05$ \\
\hline Helicobacter antibodies IgG & 10 & 45.45 & 6 & 50.00 & 0.06 & $>0.05$ \\
\hline $\begin{array}{l}\text { Serum Leptospira spirochete } \\
\text { antibodies IgG }\end{array}$ & 5 & 22.72 & 5 & 41.66 & 1.34 & $>0.05$ \\
\hline $\begin{array}{l}\text { Stool PCR of Leptospira } \\
\text { spirochete }\end{array}$ & 7 & 31.81 & 9 & 75 & 5.81 & $<0.05$ \\
\hline
\end{tabular}




\section{Discussion:}

Sewerage network workers are exposed to a multitude of biological hazards. Of these serious biological hazards are the occasional exposure to HAV, HBV, Helicobacter pylori, and leptospira spirochete (Thorn and Kerekes ,2001). We aimed in this study to investigate whether there was actual risk to the group of workers compared to the control group and, if there was a difference, to what extent this affect their health.

Many researches reported that cigarette smoking may cause abdominal pain, and discomfort ( Bardel et al., 2009). However, cigarette smoking, as a confounding factors, has been reported to cause many different symptoms. In our study, by using X2 , there was no statistically significant difference between sewage workers and controls as regards smoking habits $\mathrm{P}>0.05$.

In our work we studied the occurrence of some infections among sewage workers and we compared them with the control group, and we found a statistically significant difference between both groups as regards the presence of chronic infection with HAV, Helicobacter pylori and leptospira spirochete. The difference between both groups as regards the occurrence of HBV infection didn't reach the level of significance (table 1). In accordance with our results (Trout and Douglas , 2000) found that sewage and wastewater contain bacteria such as Helicobacter pylori and of leptospira spirochete, fungi, parasites, and viruses especially HAV and HBV that can cause intestinal, lung, liver and other infections. If equipment, work practices, and personal protective equipment (PPE) do not protect the worker from swallowing these agents, he can get sick. And during any part of treatment, transport, or application of sewage sludge, you can be exposed to materials that can cause disease. This is true even if he follows careful work habits. In agreement with our results (Ambekar et al., 2004) also said that leptospira spirochete infection causing leptospirosis is an important occupational disease affecting people coming in contact with animals and their discharges. Rodents usually abound in underground sewers and are carriers of leptospira. The urine of rodents and other animals present in that area is likely to contaminate these sewers. Thus sewer workers are at a potential risk of leptospirosis. Jeggli et al., 2004 found also that workers exposed to sewage may have an increased risk of infection by Helicobacter pylori and hepatitis E virus (HEV). In our work we used HBsAg as indicator of the presence of carrier state. Brook et al., 1998 stated that the presence of antigens in the blood 
for long time, as in carrier state, may increase the insult to the liver with damage of its cells. ACGIH, 2004 reported that no cases of HBV have been linked with sewage exposure. HBV would be very diluted in sewage and is not transmitted by inhalation or the oral-fecal route.

In our research, we found that there was a statistically significant difference between the exposed and the control groups as regards the presence of abdominal pain and body ache as shown in (table 2), but there was no statistically significant difference between both groups as regards history of jaundice. In agreement with our findings Sharma et al., 2006 reported that leptospirosis is a severe spirochetal zoonosis and is considered an occupational disease of persons engaged in agriculture, sewage works, forestry, and animal slaughtering. Their study was conducted with an objective of assessing the seroprevalence of leptospirosis among the high-risk groups of Andaman Islands. They found that antibodies to leptospira were detected in 322 samples giving an overall seroprevalence of $52.7 \%$. The seroprevalence was highest among sewage workers . These workers were admitted to the public health center (PHC) with complaints of fever and body ache and abdominal pain. Kist et al., 2005 found also that more than one-half of the world population is infected with Heli- cobacter pylori. Of those, approx. 500,000 die from gastric carcinoma every year. Non-invasive tests that do not require endoscopy include the H. pylori stool antigen by ELISA and serology, and all these people had abdominal pain. In agreement with our findings (Thorn and Kerekes , 2001) reported that work in sewage water plants can involve exposure to different types of microorganisms and chemicals. The bacterial exposure is dominated by bacteria that occur in nature. However, different pathogenic bacteria and viruses can be present in this environment and thus there exists a risk of infection, especially of hepatitis A. Investigations suggest that gastrointestinal tract symptoms are more common among employees at sewage treatment plants than among controls. The cause of the symptoms is unknown, although certain data suggest that they are caused by inflammation. The results suggest that endotoxin of Gram-negative bacteria may be one of the causative agents. Jaundice was not reported as it occurs in acute disease only and many workers had subclinical infection.

In our study there was a statistically significant difference between the sewage workers $\leq 40$ year and those $>40$ years as regards leptospira spirochete infection, however the difference between the two groups with regard to $\mathrm{HAV}, \mathrm{HBV}$ and helicobacter 
infections was not statistically significant as shown in (table 3). Contrary to our findings Sameer et al., 2006 detected antibodies to leptospira in 322 samples giving an overall seroprevalence of $52.7 \%$. The seroprevalence was highest among agricultural workers $(62.5 \%)$ followed by sewage workers (39.4\%), animal handlers (37.5\%), forest workers (27.3\%), and butchers (30.0\%). Seroprevalence among control population was $14.7 \%$, which was comparatively less than that of the high-risk population groups and these results had no statistically significant correlation with the age of the workers. This difference between our work and the above research may be due to the small size in our study. In accordance with our results Friis et al., 1996 reported an increased risk for gastric cancer among sewage workers in several studies. During the last decade Helicobacter pylori has emerged as one important risk factor for gastric cancer and is now considered a class I carcinogen by the International Agency for Research on Cancer. Infection with Helicobacter pylori was not related to the age of the workers, but the development of gastric carcinoma was positively correlated with the age of workers. Risk to the public's health from sewage exposure was demonstrated in a 1988-1989 epidemic of hepatitis A in Ocoee, Florida, that resulted in 39 cases. Each had a history of contact with sewage-contaminated storm water. Over 120 different viruses are excreted in human feces and urine and their way into sewage, that can result in chronic and severe intestinal disease in both adults and children (Vonstille et al, 1993). .

We demonstrated that there was a statistically significant difference between the sewage workers $\leq 40$ year and those $>40$ years as regards abdominal pain and body ache, but there was no statistically significant difference as regards history of jaundice as shown in (table 4). In accordance with our work ACGIH, 2004 reported that working in or around raw sewage may expose construction workers to various disease organisms. Headache, gastrointestinal distress and other symptoms may appear that could negatively impact worker comfort, safety and productivity. These symptoms increased with age and this was explained by the effect of negligence of treatment not due to the effect of age. In agreement with our results Dounias and Rachiotis, 2006 reported that total antibodies against Hepatitis A virus (HAV) were significantly high among sewage workers, and they reported also that occupational exposure to waste, age and duration of employment were significantly associated with the prevalence of abdominal pain and body ache. This research showed also that duration of employment was significantly 
associated with anti-HAV. And this result was against our findings as we found that there was no statistically significant difference between sewage workers $\leq 20$ years duration of exposure and those $>20$ years as regards $\mathrm{HAV}, \mathrm{HBV}$, Helicobacter pylori , but there was a statistically significant difference between both groups as regards leptospira spirochete infection as shown in (table 5). This could be explained by the fact that, in our work most of the examined workers were around 20 years duration and the variation between them as regards the duration of work was not more than 2 years, in addition to the small sample size. Also we found in our study that there was no statistically significant difference between sewage workers $\leq 20$ years duration of exposure and those $>20$ years as regards different symptoms, by using X2, P >0.05. This is explained by the same reasons mentioned above. In accordance with our findings Donald, 2005 found that raw sewage may contain various disease organisms including bacteria, viruses, fungi, worms and protozoa. Bacterial concentrations are typically highest wherever sewage is agitated, such as near incoming wastewater inlets and sludge treatment areas . However, contractors and workers should not assume that any area is necessarily clean. Airborne bacteria have been found in "clean" areas such as control rooms. The primary route of exposure to these organisms is hand-to-mouth contact or the "fecal-oral route" . This can occur during eating, drinking or smoking, or by touching the face with contaminated hands or gloves, and this was not related to duration of work. However, studies have shown increased risk of occurrence of symptoms associated with infection (e.g., headache, gastrointestinal upset, dizziness, eye irritation ,body ache), and indications of subclinical infection such as the presence of antibodies to a particular disease organism. These symptoms were also not related to the duration of work.

\section{Recommendations:}

Biological health hazards could be prevented through engineering, medical and legislative measures. While the engineering measures will help in protecting against exposures, the medical measures will help in early detection of the effects of these exposures. This can be partly achieved by developing an effective occupational health service for this group of workers. Also, regular awareness programs should be conducted to impart knowledge regarding safer work procedures, the use of personal protective devices, and to avoid direct contact with raw sewage. For pipeline or other inspections, remote-controlled robotic cameras can minimize human exposure. 